\title{
Tabularia
}

TABULARIA Sources écrites des mondes normands médiévaux

Autour de Serlon de Bayeux : la poésie normande aux $\mathrm{XI}^{\mathrm{e}}-\mathrm{XI}{ }^{\mathrm{e}}$ siècles | 2017

\section{Textual errors in Serlo of Bayeux's poem about the capture of Bayeux}

Erreurs textuelles dans les poèmes de Serlon de Bayeux sur la prise de Bayeux

Errori testuali nel poema di Serlone di Bayeux sulla presa di Bayeux

\section{Moreed Arbabzadah}

\section{(2) OpenEdition}

\section{Journals}

Electronic version

URL: http://journals.openedition.org/tabularia/2951

DOI: 10.4000/tabularia.2951

ISSN: $1630-7364$

Publisher:

CRAHAM - Centre Michel de Boüard, Presses universitaires de Caen

Electronic reference

Moreed Arbabzadah, "Textual errors in Serlo of Bayeux's poem about the capture of Bayeux »,

Tabularia [Online], Autour de Serlon de Bayeux : la poésie normande aux XIe-XIIe siècles, Online since 21 December 2017, connection on 21 April 2019. URL : http://journals.openedition.org/tabularia/2951 DOI : 10.4000/tabularia.2951 



\title{
Textual errors in Serlo of Bayeux's poem about the capture of Bayeux
}

\section{Erreurs textuelles dans les poèmes de Serlon de Bayeux sur la prise de Bayeux}

\section{Errori testuali nel poema di Serlone di Bayeux sulla presa di Bayeux}

\author{
Dr Moreed ARBABZADAH \\ Fitzwilliam College, Cambridge, UK \\ mra34@cam.ac.uk
}

\begin{abstract}
:
Current editions of Serlo of Bayeux's poem about the capture of Bayeux in 1105 contain numerous errors. The most important editions are those of Wright and Brial; I therefore focus on their editions in this article. I provide an example of an error in the Latin text printed by Wright, which probably results from the incorrect interpretation of a gloss. I then turn to Brial's editions and provide some examples of various types of error in his works. I then discuss errors common to Brial and Wright and propose solutions. Finally, I discuss an unsolved problem.
\end{abstract}

Keywords: Serlo of Bayeux, capture of Bayeux, Latin verse, Leonine hexameters, rhyme, manuscript BL Cotton Vitellius A. xii, Medieval Latin

\section{Résumé:}

Les éditions du poème de Serlon de Bayeux sur la prise de Bayeux en 1105 contiennent un grand nombre d'erreurs. Les éditions les plus importantes ont été écrites par Wright et Brial; par conséquent, ces éditions seront examinées dans cet article. Après avoir d'abord donné un exemple d'une erreur de Wright, issue probablement de la mauvaise interprétation d'une glose, je mettrai en évidence quelques-unes de celles qui ont été commises par Brial, qui sont de divers types. J'examine ensuite les erreurs faites par les deux éditeurs et je suggère quelques solutions. J'examine enfin un problème qui n'est pas résolu.

Mots-clés: Serlon de Bayeux, prise de Bayeux, vers latin, hexamètres léonins, rime, manuscrit BL Cotton Vitellius A. xii, latin médiéval

\section{Riassunto:}

Le edizioni del poema di Serlone di Bayeux sulla presa di Bayeux nel 1105 contengono un gran numero di errori. Le edizioni più importanti sono state realizzate da Wright e Brial; di conseguenza, esse saranno esaminate nel presente articolo. Dopo aver fornito esempio di un errore di Wright, determinato probabilmente dalla cattiva interpretazione di una glossa, evidenzierò alcuni dei diversi tipi di errori commessi da Brial. In seguito analizzerò gli errori comuni ai due editori proponendo qualche soluzione. Infine poi, tratterò di un problema non ancora risolto.

Parole chiave: Serlone di Bayeux, presa di Bayeux, verso latino, esametri leonini, rima, manoscritto BL Cotton Vitellius A. xii, latino medievale

Tabularia "Études», "Autour de Serlon de Bayeux...", 2017, p. 1-14, 21 décembre 2017 URL: http://journals.openedition.org/tabularia/2951 | DOI: 10.4000/tabularia.2951 
In memory of Leonard Marshall. I would like to thank Elisabeth van Houts, Marie-Agnès Lucas-Avenel and the editorial committee of Tabularia for their comments. I am especially grateful to Michael Reeve, who provided numerous corrections and suggestions. Any remaining errors are mine alone.

\section{Introduction}

No current edition of Serlo of Bayeux's poem on the capture of Bayeux is free from textual errors in the Latin. Some of these can be traced back to scribal errors in the manuscript, whilst others are due to subsequent editors. I will show why some readings are impossible or unlikely and attempt to suggest solutions to these problems ${ }^{1}$. By illustrating the deficiencies of the editions currently available, I hope to provide some justification for a new edition of Serlo's poetry, a project on which I am currently working with Edoardo D'Angelo and Marie-Agnès Lucas-Avenel ${ }^{2}$. I will give examples even of minor errors in current editions in order to provide an indication of the mistakes that mar them.

The poem is found in only one manuscript (BL Cotton Vitellius A. xii, fols. 110v-112v), in which it is introduced by the following rubric: Incipiunt uersus Serlonis de capta Baiocensium ciuitate. It is part of a short booklet (fols. 109-135) that was written $c .1200$ and contains poems from the late $\mathrm{XI}^{\text {th }}$ and early XII ${ }^{\text {th }}$ centuries $^{3}$. The hand is protogothic (though various other names, e.g. pregothic, have been proposed $)^{4}$ : angularity is visible in, for example, the forms of $r, m, n$ and $o$; the shaft of $a$ is generally vertical; $f$ and half-uncial (long and straight) $s$ stand on the baseline; half-uncial $s$ is the usual form, but uncial $s$ is occasionally to be found in final position in short, abbreviated words ${ }^{5}$; both the uncial and half-uncial (upright) forms of $d$ occur; there are two forms of $r$; both tironian $e t$ and the ampersand appear; abbreviations are relatively frequent, including 9 for $c o n, s$; for sed, $\div$ for $e s t, \bar{c}$ for cum and $\bar{n}$ for non; de is found with the $e$ attached to the top of an uncial $d$, a XII ${ }^{\text {th }}$ century development ${ }^{6}$; the general abbreviational mark is a superscript line that curves upwards on the right; the final downward stroke of $h$ turns towards the left; $c t$ and $s t$ are ligatured; minims have feet that hook upwards and to the right in a fine stroke; there is little evidence of biting; the punctuation marks found are the punctus (.) level with the baseline, the punctus versus (;), the punctus elevatus and (with a similar form) the punctus interrogativus; red and green are used for initials; damage to the top of each leaf makes it impossible to see whether the scribe has written above or below the top line ${ }^{7}$.

1. In all quotations from modern editions I have standardised the orthography (i.e. spellings and the use of capital letters), but I have left the editor's punctuation intact. In quotations from the manuscript I have classicised the orthography and adapted the punctuation.

2. See also the article by D'Angelo and Lucas-Avenel in this volume of Tabularia.

3. RIGG 1992, p. 150-151.

4. See Derolez 2003, especially p. 56-71.

5. Cf. Derolez 2003, p. 63-64.

6. BISCHOFF 1990, p. 122.

7. The move from writing above the top line to below it occurred in the XIII ${ }^{\text {th }}$ century: see KeR 1960. 
The original poem must have been composed after the capture of Bayeux (April 1105) but before Serlo's death, which occurred between 1113 and 1122; if a duke referred to in the poem is Robert Curthose, then it must have been written before September $1106^{8}$. Of all the poems attributed to Serlo, this one is perhaps the most historically interesting and important, because it provides an eyewitness account of Henry I's conquest of Bayeux. Other poems attributed to Serlo are of interest for the study of the history of clerical marriage 9 .

The manuscript is mostly legible: it was damaged in 1731 by the fire that broke out at Ashburnham House in London, where the Cotton library was kept. The top of each leaf was damaged, rendering some lines partially or totally illegible. The poem consists of 339 Leonine hexameters arranged in two columns on each page: lines 1-20, fol. 110v, column 2; lines 21-62, fol. 111, column 1; lines 63-104, fol. 111, column 2; lines 105-146, fol. 111v, column 1; lines 147-188, fol. 111v, column 2 ; lines $188-229$ (line 188 is repeated by the scribe), fol. 112 , column 1 ; lines 230-271, fol. 112, column 2; lines 272-313, fol. 112v, column 1; lines 314-339, fol. 112v, column 2. Unlike the dactylic hexameter of Classical Latin, the Leonine hexameter rhymes the two syllables preceding the caesura in the third foot with the final two syllables of the line, e.g. corde fero tristi quod tam cito capta fuist $i$ (line 1$)^{10}$. In this poem there is always a masculine caesura in the third foot ${ }^{11}$.

The two most important editions of the Latin text are BRIAL 1833 and WrIGHT 1872. The editions of Pillet and Pluquet are both based on BRIAL 1827. Pluquet 1829 is directly based on Brial $1827^{12}$, whilst Pillet 1839 is based on Pluquet 1829 (and is therefore indirectly based on BRIAL 1827) ${ }^{13}$. BRIAL 1833 includes some extra notes but is otherwise almost identical to BRIAL 1827. I therefore use "Brial" to signify the consensus of the 1827 and 1833 editions. BRIAL \& DeLISLE 1880 is identical to BRIAL 1833. Of all these editions, only PLUQUET 1829 offers a translation (into French). BöHMER 1897 discusses various poems attributed to Serlo; with regard to the poem on the capture of Bayeux, Böhmer notes numerous discrepancies between Wright 1872 and Brial \& DelisLe 1880. He sometimes indicates his objection to a reading by adding an exclamation mark in parentheses after it; he rarely offers any explanations or comments ${ }^{14}$.

Wright's edition does not print line numbers, so I have added them myself. Note that the line numbers in Brial's editions differ from the ones I have added to Wright's edition after line 255 (see below for an explanation for the discrepancy). Where the line numberings of Wright and Brial diverge, I use square brackets,

8. VAN Houts 2013, p. 72.

9. See, for example, van Houts 2013.

10. See D'ANGELO 2014 for a discussion of Serlo's hexameters. See RIGG 1996 for a very brief overview of Medieval Latin metrics. More detailed discussions can be found in the following: RIGG 1992, p. 313-329; Norberg 1958 (in French); Norberg 2004 (an English translation of Norberg 1958, with a new introduction by Jan Ziolkowski); LEONHARDT 1989.

11. D'ANGELO 2014, p. 312.

12. Pluquet 1829, p. 140.

13. Pillet 1839, p. 5.

14. BÖHMER 1897, p. 717. 
e.g. [328], to represent the line number in Brial's editions; line numbers without brackets correspond with the manuscript and Wright.

Appendix 2 of vaN Houts 2014 contains full references (citing manuscripts, editions and secondary literature) for nine poems attributed to Serlo ${ }^{15}$. In Appendix 3 of van Houts 2014 I offered a new text and translation of this poem, as well as brief textual notes that sometimes cover points that will be discussed below ${ }^{16}$. The opinions in this article supersede those earlier ones.

\section{Errors in Wright's edition}

George Rigg quotes Sidney Lee's judgement that much of Wright's "work was hastily executed, and errors abound, but his enthusiasm and industry were inexhaustible"; Rigg specifically mentions that Wright sometimes transcribes the manuscript incorrectly ${ }^{17}$. The following reading appears to be an example of this phenomenon:

Wright 329 et pretio dantis, uel doni me decorantis.

"(clothes doubly welcome to me,) because of the worth of my benefactor or of the gift adorning me."

Wright sees that something is wrong: "So the MS apparently"18. The previous line has causa duplici mihi gratum, "(clothes) welcome to me for a double reason". Hence uel is out of place here, since the clothes are welcome not for either one reason or a different reason, but for both reasons. Long before Wright, however, Brial had printed the following text (which Böhmer subsequently supported $)^{19}$ :

Brial 329 [328] et pretio dantis, tunicae quoque me decorantis.

"(clothes doubly welcome to me,) because of the worth of my benefactor and of the cloak adorning me."

Wright's error is easily explained by an examination of the manuscript, which presents the following text (which I have redrawn):

\section{t donc Tunice}

\footnotetext{
15. VAN HouTs 2013, p. 81-85.

16. VAN Houts 2013, p. 86-105.

17. RIgG 1977, p. 115.

18. WRIGHT 1872 , p. 251.

19. BÖHMER 1897, p. 717.
} 
Clearly doni is written by the scribe as a gloss introduced by an abbreviation for $u e l$. Since uel doni was able to replace tunicae quoque without making the line metrically impossible, tunicae quoque was replaced in the transcription provided to Wright.

It is odd, however, for the general term (doni) to be used to gloss the specific term (tunicae). The reverse would be more common, since tunicae explains what the doni is. The sense would also be improved by having dantis contrasted with doni. Perhaps Serlo wrote doni quoque, after which doni was glossed as tunicae; the scribe of the Cotton manuscript could then have swapped the positions of doni and tunicae.

The comment by Wright interestingly suggests that he did not examine the manuscript himself. Presumably he was relying on the report of someone else: when he examined their transcription, he was not able to be sure that it was incorrect, since he could not examine the manuscript himself. Doubting the text, he therefore added a comment in order to indicate that he did not entirely believe the transcription.

\section{Errors in Brial's editions}

Since the failings of Wright's editions are already well known, I turn now to some of the errors in the editions by Brial.

(i)

Brial $\quad 81$ nam re sic gesta (et potior mors esset honesta)

Line 81 in this form seems unlikely for two reasons ${ }^{20}$. Firstly, the elision in this position in the line is unparalleled in the rest of the poem. In fact the only other clear example of elision is in line 141 (quando est multorum conuersio facta uirorum, "when the conversion of many men was accomplished") ${ }^{21}$. Given how rare elision is in this poem it would be wise to be sceptical about line 81 . Secondly, it is worth noting that the elision in 81 affects the final syllable of gesta, which forms the rhyme with honesta. Should we therefore emend this line? In fact emendation is unnecessary, because an examination of the manuscript reveals that $e t$ was not present in the first place. There is, however, a punctuation mark between gesta and potior: obviously this mark was misread as an abbreviation for et. Böhmer sees that the elision here is problematic and that et needs to be deleted, but clearly does not know that the manuscript does not have $e t^{22}$. The text as it stands makes perfect sense:

20. The difference in vowel length (gestā... honestă) is not a problem. Rhymes such as uult ̌̌s... multīs and prōnus... bŏnus are perfectly acceptable in Leonine hexameters: see RIGG 1992, p. 315 and STRECKER 1968, p. 76.

21. There is another example (275 o armis), but I believe that this should be emended (see below). On elision in Serlo's poetry, see D'ANGeLo 2014.

22. BöHMER 1897, p. 717. 
"People of Bayeux, such fear proves that this mortal life is too dear to you. An honest death would be better than acting like this."

(ii)

Brial 187 ergo sacrati, metuebant qui prius uri,

Brial comments that sacrati must be corrupt because it should rhyme with uri, so he suggests that perhaps the text should read sacraturi ${ }^{23}$. Böhmer uses an exclamation mark to show his objection to sacrati ${ }^{24}$. The conjecture sacraturi is unnecessary, since the manuscript has securi, not sacrati:

ms $\quad 187$ ergo securi, metuebant qui prius uri,

188 sacra reliquerunt loca quam citius potuerunt

"So (the clergy), who previously feared being burned, safely left the sacred places as quickly as possible."

(iii)

I will now examine examples of metrically-impossible readings in Brial.

Brial 50 pulsabatque fores, $u t .$. interiores

51 depraedaretur, si copia forte daretur.

In a note he suggests that recessus could fill the gap in the manuscript ${ }^{25}$; recessus is repeated in later works, but does not scan and so must be abandoned.

$$
\begin{aligned}
& --|-\smile-1-\smile--|--\smile \mid-- \\
& 50 \text { pulsabatque fores, ut recessus interiores }
\end{aligned}
$$

This would only scan if $u t$ were treated as short before $r$-, which is not possible. The blank space in the manuscript after $u t$ is approximately 11 letters and/or spaces wide. This could be filled by a word approximately nine letters in length, preceded and followed by a space. This would fill the gap, but there is nothing to guarantee that only one word has been lost, or indeed that the gap is the same size as whatever appeared in Serlo's original text. There is little that can be done beyond the suggestion of a metrically-suitable conjecture that

23. "Mendose scripta vox; sed quomodo corrigenda ut consonet ultimis versus syllabis uri? forte sacraturi." (BRIAL 1833, p. xciv).

24. BÖHMER 1897, p. 717.

25. “Forsan recessus." (BRIAL 1833, p. xcii). 
would fit the context: we need (at least) a noun for interiores to modify. Various suggestions that would scan have been made: Pillet prints $u t \ldots$ interiores and notes "fortasse sedes vel partes" ${ }^{26}$. Reeve offers gazas. I have previously suggested census as an option: cf. the use of census earlier in the poem (34-35 ardet succensus qui per mala plurima census / accumulatus erat, si quis bene singula quaerat) ${ }^{27}$. It is worth noting that Wright prints $u$ trecessus interiores, commenting that it is damaged in the manuscript, but without attributing recessus to Brial ${ }^{28}$.

(iv)

Brial 95 litibus atque minis sit per haec tempora finis,

Brial's text does not scan and clearly results from an abbreviation being misunderstood during transcription. The manuscript has the correct reading:

ms 95 litibus atque minis sit post haec tempora finis,

"let there be an end after this to quarrels and threats"

(v)

Brial 225 pace caret uenter; pugnat is indesinenter

Note that indesinenter (which Böhmer supports) cannot be correct ${ }^{29}$, since a cretic cannot occur in any position in a hexameter:

$--\smile-$

indesinenter

Clearly pugnat is would be metrically impossible in the position in which it appears. Once again, we have transcription errors:

ms 225 pace caret uenter, pugnans indeficienter

"(Until it purges itself, just as so heavy a load urges,) my stomach lacks peace, fighting incessantly"

(vi)

$$
-\smile \backsim 1 \smile
$$

Brial 232 est itaque nudo uehemens mihi sollicitudo,

\footnotetext{
26. Pillet 1839, p. 7.

27. VAN Houts 2013, p. 88.

28. WRIGHT 1872 , p. 243.

29. BÖHMER 1897, p. 717.
} 
Again, Brial's text is implausible (-que would have to scan as a heavy syllable here) and is clearly the result of an incorrect transcription:

$\mathrm{ms}$

232 est etiam nudo uehemens mihi sollicitudo,

"There is another great source of anxiety for me in my state of destitution"

Böhmer uses an exclamation mark to show his objection to itaque nudo, but does not provide a correction ${ }^{30}$.

\section{(vii)}

At one point Brial omits an entire line from the manuscript (as noted by Böhmer) ${ }^{31}$, resulting in a difference in line numbering (as I have mentioned above):

Brial 254 fias mendicus, tibi non remanebit amicus.

[255] qui mihi cognati fuerant, mutatio fati,

[256] quae censum laesit, facit ut cognatio desit.

$\mathrm{ms}$

254 fias mendicus, tibi non remanebit amicus.

255 non ipsi curant mala me quaecumque perurant,

256 qui mihi cognati fuerant; mutatio fati,

257 quae censum laesit, facit ut cognatio desit.

This is presumably an error, since he does not comment on the omission.

\section{(viii)}

At line 263 [262] Brial has nihil where the manuscript reads caret $^{32}$. This is presumably dittography caused by the presence of nil later in the line:

Brial 262 [261] ut locuples fiam non exercebo sophiam;

263 [262] hac mercede labor nihil, hac nil arte lucrabor.

ms

262 ut locuples fiam, non exercebo sophiam:

263 hac mercede labor caret; hac nil arte lucrabor.

(ix)

Brial's editions are also not entirely clear when it comes to recording conjectures. In line 45 the manuscript has properauit, which would not scan, but Brial prints properant, which is clearly the correct reading (as recognised by Böhmer) ${ }^{33}$ :

30. BÖHMER 1897, p. 717.

31. BÖHMER 1897, p. 717.

32. Böhmer notes that here Brial differs from Wright, but gives no sign as to the correct reading (BÖHMER 1897, p. 717)

33. BÖHMER 1897, p. 717. 
$\mathrm{ms}$

44 tunc clausae milia gentis,

$-\smile \smile|--|-\smile \smile \mid-\smile-$

45 tacta metu mortis, properauit erumpere portis;

Brial

$$
\begin{array}{r}
44 \quad \text { tunc clausae milia gentis, } \\
-\smile \smile|--|-\smile-\mid-- \\
45 \text { tacta metu mortis, properant erumpere portis; }
\end{array}
$$

"At that point, the thousands of people shut inside rush to leave through the doors, moved by their fear of death"

$(x)$

In line 198 the metre shows that something is missing:

$\mathrm{ms}$

$$
-\smile \smile \mid-\smile-
$$

198 huius odore me paene uomendo rigaui,

Brial cleverly reads odore graui me and by the simple addition of graui restores the metre and the rhyme:

Brial

$$
-\smile \backsim 1-\smile \backsim 1-
$$

198 huius odore graui me paene uomendo rigaui,

His solution is elegant because it is easy to see how a scribe would miss graui in line 198 due to the appearance of granis in the line above it (line 197):

Brial 196 nescio si nostis; sed ego noui, quia, tostis

197 compositus granis, uix transit guttura panis.

198 huius odore graui me paene uomendo rigaui,

"I do not know if you know; but I have learned that bread made from burnt grain scarcely passes through the gullet. I almost spewed forth vomit at the acrid smell of it"

Yet neither graui nor properant is marked as a conjecture. I have not necessarily included every possible example; but it should be clear that Brial does not consistently record whether he is using a manuscript reading or his own conjecture. This is unfortunate, because he often deserves credit for the intelligent solutions that he has proposed. As I have also shown, however, he not infrequently prints a text that is manifestly incorrect, and these errors often result from simple misreadings of the manuscript.

(xi)

On at least one occasion Brial makes an error that I cannot explain. At the end of line 278 [277] he has aeternum: 
Brial 278 [277] qui grandem quaestum, nomenque merentur aeternum.

This is the text as it appears in BRIAL 1827 and BRIAL 1833, yet in the later edition he adds a comment noting that it should be emended to honestum ("Mendosissima lectio: scribendum profecto erat honestum"), although he still prints aeternum in the text ${ }^{34}$. Böhmer gives an incorrect line number (279) and uses an exclamation mark to signal that aeternum is wrong ${ }^{35}$. The manuscript has the correct reading, honestum:

$\mathrm{ms}$

277 nil illis gratum profert facundia uatum

278 qui grandem quaestum nomenque merentur honestum.

"The eloquence of poets offers nothing pleasing to those who deserve great riches and an honoured name."

\section{Errors found both in Brial's editions and in Wright's edition}

There are times when neither the manuscript nor Wright nor Brial provides an acceptable reading.

(i)

At line 322 the manuscript (followed by Wright) provides an unmetrical text:

ms $\quad 322$ pecte si leni fieret prece uatis egeni,

323 non tot ei grates deberet reddere uates;

Line 322 [321] begins with puta in Brial, although he comments that the text here seems corrupt ${ }^{36}$ :

Brial $\quad 322$ [321] puta si leni fieret prece uatis egeni,

323 [322] non tot ei grates deberent reddere uates:

He is indeed correct, since puta could not scan in this position. He presumably takes püta to be an imperative from the verb puto with the meaning "think, consider". The reading of the manuscript is no better (pecte "comb", as in "comb your hair", an imperative from pecto). Böhmer notes (with his customary exclamation mark) that Brial's deberent (for which the manuscript has the correct reading, deberet) and puta are incorrect; he suggests pectore for

\footnotetext{
34. BRIAL 1833 , p. xcvi.

35. BÖHMER 1897, p. 717.

36. "Videtur hic mendum aliquod irrepsisse." (BRIAL 1833, p. xcvii).
} 
puta $^{37}$, which could work if taken with leni and understood as referring to the person to whom Serlo owes a debt ${ }^{38}$ :

320 et tamen est unus, cui magnum debeo munus:

321 nam mihi sponte dedit, quod honestum mens mea credit.

322 pectore si leni fieret prece uatis egeni,

323 non tot ei grates deberet reddere uates:

324 non gratis dantur, prece munera si qua parantur.

"And there is however one person to whom I owe a great service, because he gave things to me of his own accord: that is something I consider honourable. If it were being done with a gentle heart at the request of a poor poet, the poet would not owe him so much gratitude: gifts are not given for nothing, if they are in any way obtained by request."

(ii)

At line 333 the manuscript (followed by Brial and Wright) reads as follows:

333 qui famat, seruat, laudesque merentis aceruat,

The verb famat is unusual, since Serlo mostly uses vocabulary attested in Classical Latin; in this poem there do not appear to be any other examples of verbs that are only attested in Late Latin. A simple change would remove famat $^{39}$ :

Reeve $\quad 332$ reddam thesaurum qui gemmas uincit et aurum, 333 qui famam seruat laudesque merentis aceruat,

"I will give him in return a treasure better than gems and gold, one which preserves a deserving person's reputation and increases their praise"

(iii)

I have noted above how rare elision is in this poem. At least one instance of elision should perhaps be removed by emendation. Line 275 [274] reads as follows in the manuscript:

ms $275[274]$ o armis ignari proceres, hebetes et auari!

Brial erroneously reads ignaui in his text but adds the correct reading in a comment in BRIAL 1833: "Melius ignari" ${ }^{40}$. He noticed, of course, that the text

37. BöHMER 1897, p. 717. He says nothing more of deberent.

38. I no longer support my previous suggestion, pactum (van HouTs 2013, p. 104).

39. Credit is due to Prof. Reeve for the identification of famat as a corruption and the proposal of famam as a solution.

40. BRIAL 1833, p. xcvi. 
he had printed did not rhyme. Pillet follows BRIAL 1827 (which does not have the note with the correct reading) and therefore translates armis ignaui as "sans courage dans les batailles" ${ }^{41}$. Böhmer seems to think the manuscript has carmis (rather than $o$ armis) and suggests it be emended to carminis ${ }^{42}$.

It is not only the elision in $o$ armis that is cause for suspicion: the syntax is also unusual. If armis is a dative or ablative plural from arma, then it would seem natural to take it as dependent on ignari (just as Pillet did with ignaui). Yet the use of a genitive with the adjective ignarus would be expected even in Medieval Latin. A simple and palaeographically-plausible solution would be to read nimis for armis:

Reeve 275 [274] o nimis ignari proceres, hebetes et auari!

"How foolish, stupid and greedy those nobles are!"

\section{An unsolved problem}

I finish now with a problem for which I know of no acceptable solution. Line 147 in the manuscript does not make sense and does not scan:

ms $\quad 147$ †atria pleni modulo nec consona leni. $\dagger$

Brial attempts to correct the problem:

Brial 147 atria plena rudi modulo, nec consona leni.

He then makes a rather strange comment: "Forsan laudi, nisi de industria auctor consonantiam hic imperfectam reliquerit" 43 .

Brial is therefore suggesting that leni should be emended to make it rhyme with rudi, even though elsewhere in this poem au only ever rhymes with $a u$, and even though rudi is a conjecture itself. Böhmer suggests ludi, which is similarly unlikely $^{44}$. I suspect that leni is correct and that the problem is with the text surrounding pleni. We can at least discount the possibility that this line did not contain a rhyme when it was composed. Every single line in the poem follows the same pattern; the only lines without a rhyme are not really exceptions, since they are merely corrupt. The general meaning of the passage seems to be as follows:

$\mathrm{ms}$

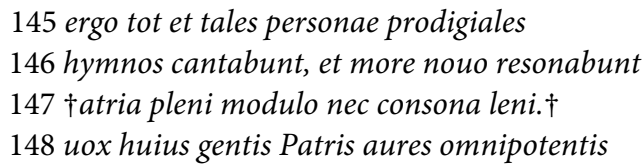

41. Pillet 1839, p. 16.

42. BÖHMER 1897, p. 717.

43. BRIAL 1833 , p. Xciv. The emphasis on consonantiam is Brial's.

44. BÖHMER 1897, p. 717. 
149 uexabit multum, grandem factura tumultum.

"Then so many excellent people will sing wondrous hymns, and the halls will resound in a new manner, †ringing with loud noise rather than pleasant music. $\dagger$ The voices of these people will greatly annoy the ears of the almighty Father and make a huge uproar."

\section{Conclusion}

Rigg noted some time ago that the absence of editions for some Medieval Latin authors is often not as problematic as the quality of the editions that have been produced ${ }^{45}$. In the case of this poem, correct readings are to be found interspersed between the manuscript, several editions and Böhmer's article. This means that any one of these sources is frustratingly riddled with mistakes. The errors in previous editions and the manuscript are perhaps not always of great importance for the understanding of Serlo's poem on the capture of Bayeux, but there are practical reasons for wanting to highlight and eliminate even the most minor mistakes. If errors in the text are left uncorrected, then scholars are in danger of basing their conclusions on a faulty text. Allowing a dubious example of elision to remain in the text risks causing scholars to draw the conclusion that such elision is acceptable in this poem and other works by Serlo. Such errors could then play a part in discussions of whether a certain text is to be attributed to Serlo on stylistic grounds.

The study of Serlo's poetry has been hindered by the lack of published translations and commentaries for the majority of the poems attributed to him. A new edition, founded on a thorough reappraisal of the Latin texts in question, would not only make Serlo accessible to a far wider audience but also provide a useful resource for those already acquainted with his work.

\section{Bibliography}

Bischoff, Bernhard, translated by Daíbhí Ó Cróinín and David Ganz, Latin Palaeography. Antiquity and the Middle Ages, Cambridge, Cambridge University Press, 1990.

BöHmer, Heinrich, "Der sogenannte Serlo von Bayeux und die ihm zugeschriebenen Gedichte”, Neues Archiv der Gesellschaft für ältere deutsche Geschichtskunde, 22, 1897, p. 701-738.

Brial, Michel-Jean-Joseph, "Notice d'un manuscrit de la bibliothèque du chevalier Cotton, faisant partie aujourd'hui du Musée britannique", in Notices et extraits des manuscrits de la bibliothèque du Roi et autres bibliothèques, Paris, Imprimerie royale, $11.2,1827$, p. 165-177.

45. RIGG 1977, p. 114. 
Brial, Michel-Jean-Joseph, Recueil des historiens des Gaules et de la France. Tome dix-neuvième, Paris, Imprimerie royale, 1833. [See p. xc-xcvii for Serlo's poem on the capture of Bayeux.]

Brial, Michel-Jean-Joseph and Delisle, Léopold, Recueil des historiens des Gaules et de la France. Tome dix-neuvième. Nouvelle édition, Paris, Victor Palmé, 188o. [See p. xc-xcvii for Serlo's poem on the capture of Bayeux.]

D’ANGELO, Edoardo, "Modèles classiques de l'hexamètre historiographique normand", in L'Historiographie médiévale normande et ses sources antiques ( $X^{e}-X I I^{e}$ siècle), Actes du colloque de Cerisy-la-Salle et du Scriptorial d'Avranches (8-11 octobre 2009), Pierre BAuduin and Marie-Agnès Lucas-Avenel (ed.), Caen, Presses universitaires de Caen, 2014, p. 307-325.

Derolez, Albert, The palaeography of Gothic manuscript books: From the Twelfth to the Early Sixteenth Century, Cambridge, Cambridge University Press, 2003.

Ker, Neil, “From 'above top line' to 'below top line': a change in scribal practice”, Celtica, 5, 1960, p. 13-16.

Leonhardt, Jürgen, Dimensio syllabarum. Studien zur Prosodie- und Verslehre von der Spätantike bis zur frühen Renaissance, Göttingen, Vandenhoeck \& Ruprecht, 1989.

Lucas-Avenel, Marie-Agnès and D’Angelo, Edoardo, "Vers une nouvelle édition des poèmes de Serlon de Bayeux", Tabularia [En ligne], Autour de Serlon de Bayeux: la poésie normande aux $\mathrm{XI}^{\mathrm{e}}-\mathrm{XII}{ }^{\mathrm{e}}$ siècles, mis en ligne le 24 octobre 2017 , consulté le 21 décembre 2017. URL: http://journals.openedition.org/tabularia/2897; DOI: 10.400o/tabularia.2897.

Norberg, Dag, Introduction à l'étude de la versification latine médiévale, Stockholm, Almqvist \& Wiksell, 1958.

Norberg, Dag, translated by Grant C. Roti and Jacqueline de la Chapelle Skubly, edited and with an introduction by Jan Zıolkowski, An introduction to the study of Medieval Latin versification, Washington, D. C., The Catholic University of America Press, 2004.

Pillet, Victor-Évremont, Serlon, Bayeux, Clément Groult, 1839.

Pluquet, Frédéric, Essai historique sur la ville de Bayeux et son arrondissement, Caen, T. Chalophin, 1829.

RIGG, Arthur George, "Medieval Latin”, in Editing medieval texts, Arthur George RIGG (ed.), New York, Garland Publishing, 1977, p. 107-125.

RigG, Arthur George, A history of Anglo-Latin literature 1066-1422, Cambridge; New York, Cambridge University Press, 1992.

RigG, Arthur George, "Metrics", in Medieval Latin, F. A. C. Mantello and Arthur George Rigg (ed.), Washington, D. C., The Catholic University of America Press, 1996, p. 106-110.

STreCKer, Karl, translated and revised by Robert B. PALMER, Introduction to Medieval Latin, Berlin, Weidmann, 1968.

VAN Houts, Elisabeth, “The fate of the priests' sons in Normandy with special reference to Serlo of Bayeux", The Haskins Society Journal, 25, 2013, p. 57-105.

Wright, Thomas, The Anglo-Latin satirical poets and epigrammatists of the twelfth century. Vol. II, London, Longman, 1872. 